\title{
Determining Factors in the Use of Urban Parks That Influence the Practice of Physical Activity in Children: A Systematic Review
}

\author{
Rosario Padial-Ruz ${ }^{1}$, $\mathbf{M}^{\mathrm{a}}$ Esther Puga-González ${ }^{1, *}$, Álvaro Céspedes-Jiménez ${ }^{2}$ and David Cabello-Manrique ${ }^{2} \mathbb{C}$ \\ 1 Department of Didactics of Musical, Plastic and Corporal, University of Granada, 18011 Granada, Spain; \\ rpadial@ugr.es \\ 2 Department of Physical Education and Sports, University of Granada, 18011 Granada, Spain; \\ alvarocespedesjimenez@gmail.com (Á.C.-J.); dcabello@ugr.es (D.C.-M.) \\ * Correspondence: mpuga@ugr.es; Tel.: +34-6075-875-23
}

check for updates

Citation: Padial-Ruz, R.; PugaGonzález, M.E.; Céspedes-Jiménez,

Á.; Cabello-Manrique, D.

Determining Factors in the Use of

Urban Parks That Influence the

Practice of Physical Activity in

Children: A Systematic Review. Int. J.

Environ. Res. Public Health 2021, 18

3648. https://doi.org/10.3390/

ijerph18073648

Academic Editor: Paul Tchounwou

Received: 22 February 2021

Accepted: 24 March 2021

Published: 31 March 2021

Publisher's Note: MDPI stays neutral with regard to jurisdictional claims in published maps and institutional affiliations.

Copyright: (c) 2021 by the authors. Licensee MDPI, Basel, Switzerland. This article is an open access article distributed under the terms and conditions of the Creative Commons Attribution (CC BY) license (https:// creativecommons.org/licenses/by/ $4.0 /$ )

\begin{abstract}
The design and/or remodelling of urban parks is a good health strategy to alleviate the lack of physical activity (PA) in children and, consequently, the different health problems derived from this. The main objective of the present study was to obtain a systematic review of the design features and characteristics that influence users' visits to urban parks and the PA engagement in them. A literature search was carried out in the Web of Science (WOS) and Scopus databases during the months of June and July 2020. After considering and applying inclusion criteria, the final review sample was formed of 31 scientific papers published between 2010-2020. The results obtained in the review lead us to conclude that the needs of the population (children and family members who care for them) and socio-economic context of the area in which they are built must be considered when constructing and/or remodelling parks. Involving community members in playground renovations can have a positive effect on park use and PA engagement in children.
\end{abstract}

Keywords: urban parks; children; user perception; design; physical activity; health

\section{Introduction}

The high rates of inactivity and sedentariness amongst children worldwide is a major problem that needs to be addressed immediately [1]. World Health Organisation (WHO) recommendations for physical activity (PA) in young people, aged 5-17 years, state at least 60 min per day of moderate to vigorous intensity activity. This activity should be mostly aerobic and should incorporate vigorous activities that particularly strengthen muscles and bones at least three times per week. However, over the past few years, we have seen an increase in the proportion of the population that does not comply with these recommendations. This includes a large number of children [2,3], with more children also coming from disadvantaged settings [4].

Inactivity at early ages can lead to high obesity rates. Excess body fat in the early stages of life can have serious health consequences at later stages, since the risk of contracting diseases derived from inactivity, such as diabetes, hypertension and coronary diseases, among others, is high and dangerous [5]. Thus, according to Omorou et al. [6], lack of PA may increase the likelihood of being obese in adulthood.

Another consequence of childhood obesity comes from the association between motor skills, PA and body composition in the pre-school stage. Diminished interaction with natural environments and the restriction of movement at increasingly younger ages can lead to poor execution of the motor tasks necessary for correct psychomotor development [7].

At a motor level, children will also present greater difficulties at a later stage when doing sports. Children with higher physical activity levels and less sedentary behaviour present better motor skills compared with those who mostly engage in sedentary pursuits, 
with the latter often unable to develop such skills adequately [8]. Nonetheless, inactivity not only causes problems at a physical and physiological level, but it also plays a fundamental role with regards to other areas, such as social and psychological areas. In the case of the psychological area, there is a greater probability of suffering from poor social and psychological health, bringing into play self-esteem issues, poor self-concept and other more serious problems such as depression and social discrimination $[9,10]$.

The acquisition of a healthy lifestyle is a global need. For the population to have appropriate habits, it is important to intervene at crucial stages such as childhood and adolescence. The family, school and peers are responsible for encouraging these patterns in children as they are the ones who shape their daily environment [3,11]. Such intervention will contribute to favourable development at later stages, such as adulthood and old age, directly improving the quality of life of all individuals [12]. Sedentary behaviour experienced during childhood may become characteristic in individuals at latter stages. This can generate problems at future stages. It is, therefore, of vital importance to promote behaviours that succeed in motivating children to perform physical exercise [13]. Several authors have defended the need to incorporate healthy lifestyle habits during the first years of children's lives [14,15]. In this way, Poeta et al. [14] urge the need to perform physical exercise from two to six years old, as weight is put on more quickly at this stage. Further, Haines et al. [15] argue that the acquisition of physical activity habits and adequate nutrition will protect children from noncommunicable diseases and obesity.

Furthermore, the regular practice of PA in school-age children, at adequate levels, is associated with important short- and long-term health benefits. It is considered protective against diseases, it improves aspects related to mental and emotional health, it improves academic performance [3,16-18] and it can even become a form of cultural and social transformation [19]. In addition, there is a reciprocal relationship between physical activity engagement at these ages and development of the motor skills and physical competencies that are fundamental for health $[20,21]$. Existing studies at early ages, such as those conducted by Carson et al. [22], Stanley et al. [23] and Timmons et al. [24], have identified positive associations between PA and adiposity, bone and skeletal, cardiometabolic, psychosocial and cognitive health $[25,26]$, and motor skill development.

Schools are ideal environments for PA promotion to students. They offer a number of opportunities, including breaktime and physical education classes, etc. Classrooms represent ideal spaces for PA, although they are not always used for such purposes. This suggests the potential for achieving PA at different times and in different spaces (physical or motor education classes, active breaks, active pauses, physical education (PE) integrated within the curriculum, etc.), with this possibly having a very positive effect on behaviour [27], cognitive function and academic performance [26]. However, the situation we are experiencing today due to Covid19 has led to a drastic reduction in PA and concomitant increase in sedentarism, bringing with it serious consequences. Thus, now more than ever, a rethinking of healthy habits in the population is required, particularly in children. This must combine PA at home with outdoor activities and sports $[28,29]$. It is very important to provide children with opportunities to exercise, and it is necessary to have safe, accessible and outdoor recreational spaces [30].

Time spent in the open air is related to positive health outcomes. For instance, it reduces the risk of immune-based diseases [31], childhood stress, symptoms of attention deficit disorders, depression, asthma, etc. and generates a sense of well-being in the child [30]. In addition to physical health, mental health benefits in children have been improved following contact with the natural environment. Activities such as exploration encourage learning, attention and reflective practice [32], development of spirituality [33] and environmental awareness, which will lead to sustainable lifestyles [34].

To achieve health-related behavioural habits within the population, socioecological models state that certain healthy behaviours are influenced by the individual, social and physical characteristics of the environment [35-41], with these having the potential to contribute positively to health promotion. Existing research based on these theories focuses 
on the influence that physical characteristics and the construction of the environment have on health behaviour and visitation frequency, in addition to the PA and social interaction that takes place in parks and green spaces [42-44].

Within the built environment, parks and urban green spaces are related to PA. They provide a fundamental framework for alleviating sedentary lifestyles amongst children and the rest of the population in general. Most offer open spaces which are accessible to all at no or little cost [45]. They are important settings for children to develop their motor skills, physical capacity and cognitive and social abilities [46]. The design of these spaces to promote outdoor PA is, therefore, an effective and easy way of instilling active lifestyles in children, regardless of age and social status [47]. Increasing the frequency of visits to parks will promote increased PA [48].

Although most urban neighbourhoods in developed countries have parks and green areas, these are rarely visited by the population $[49,50]$. This is often because of the social environment surrounding them (insecure environments) [51] and sometimes because of their unattractive design [52,53]. Currently, apart from the exceptionality of the situation experienced by Covid19, parental concern about road safety and the danger posed by strangers is one of the reasons why the number of children going to parks has reduced. This has led to a limiting of children's independent mobility and their resultant PA engagement [53]. Another motive for park avoidance is its design. Authors such as Hyndman et al. [54] suggest that it is important that the characteristics and design of the park are appropriate because not all parks are the same in terms of their potential for promoting PA [55]. Factors such as the amount of space available, layout and safety of the park should be carefully considered when designing a playground project. Most playgrounds comprise a "traditional" design (understanding by traditional parks such as those provided with metal structures such as swings, slides, seesaws, ladders and fireman's sticks.). This may be one of the reasons why the number of visitors to such places is decreasing. Therefore, planners should take into account the factors that attract different groups of children to parks [50], as well as better understanding of how parks can be designed or redesigned in order to ensure optimal use by children and encourage increased PA from an early age [56,57].

The aim of the present study was to carry out a systematic review of the scientific literature in order to obtain a deep insight into the factors that can influence the use of parks and the increase of PA in them, both from the point of view of design and perception of users of playgrounds.

\section{Materials and Methods}

The present study follows the guidelines of the PRISMA statement (Preferred Reporting Items for Systematic reviews and Meta-Analyses) [58,59].

\subsection{Eligibility Criteria}

After establishing the study population, the research sample was selected according to the following inclusion criteria: (1) scientific papers focused on the search terms; (2) published between 2010-2020; (3) focused on the user and infrastructure characteristics of urban park design for public use; (4) interventions aimed at improving physical activity in children aged 1-12 years; (5) perceptions of parents or caregivers on the level of satisfaction of the parks. The age range selected in the inclusion criteria (1 to 12 years) is justified given the importance of the acquisition of health habits at these ages, being also a stage where the level of sedentary lifestyle has increased considerably in recent years. Papers were also included whose sample contained, in addition to the selected age, other age ranges since they were multigenerational studies. Those papers that focused exclusively on adolescents and those that did not seek to improve the quantity and quality of physical activity of the ages under study were discarded. 


\subsection{Information Sources and Search Strategies}

The literature search was conducted during June and July 2020, using Web of Science (WOS) and Scopus databases as the main search engines. For initial article selection, references were analysed which examined the characteristics and designs of public urban parks whilst also considering users' perceptions of them, with the aim of increasing their use and physical activity engagement in children. To this end, we used the terms "playgrounds", "urban parks", "physical activity" and "children" as keywords, using "and" and "or" as Boolean operators. We limited the time range of publication to the last decade (2010-2020) and only considered references published in English and Spanish. All scientific papers were included without excluding any research design. In this way, a total of 235 publications were obtained. Once the population was selected, (1) scientific papers focused on search terms were applied as the first inclusion criterion. This criterion was applied by first reading the title and summary of the study population to check that the paper met the first criterion. Subsequently, a systematic reading of the full text was carried out in order to apply the remaining criteria: (2) published between 2010-2020; (3) focused on the user and infrastructure characteristics of urban park design for public use; (4) interventions aimed at improving physical activity in children aged 1-12 years; (5) perceptions of parents or caregivers on the level of satisfaction of the parks.

Those papers that focused exclusively on adolescents and those that did not seek to improve the quantity and quality of physical activity of the ages under study were discarded. Finally, selected papers were organised and assigned an identification number (Figure 1).
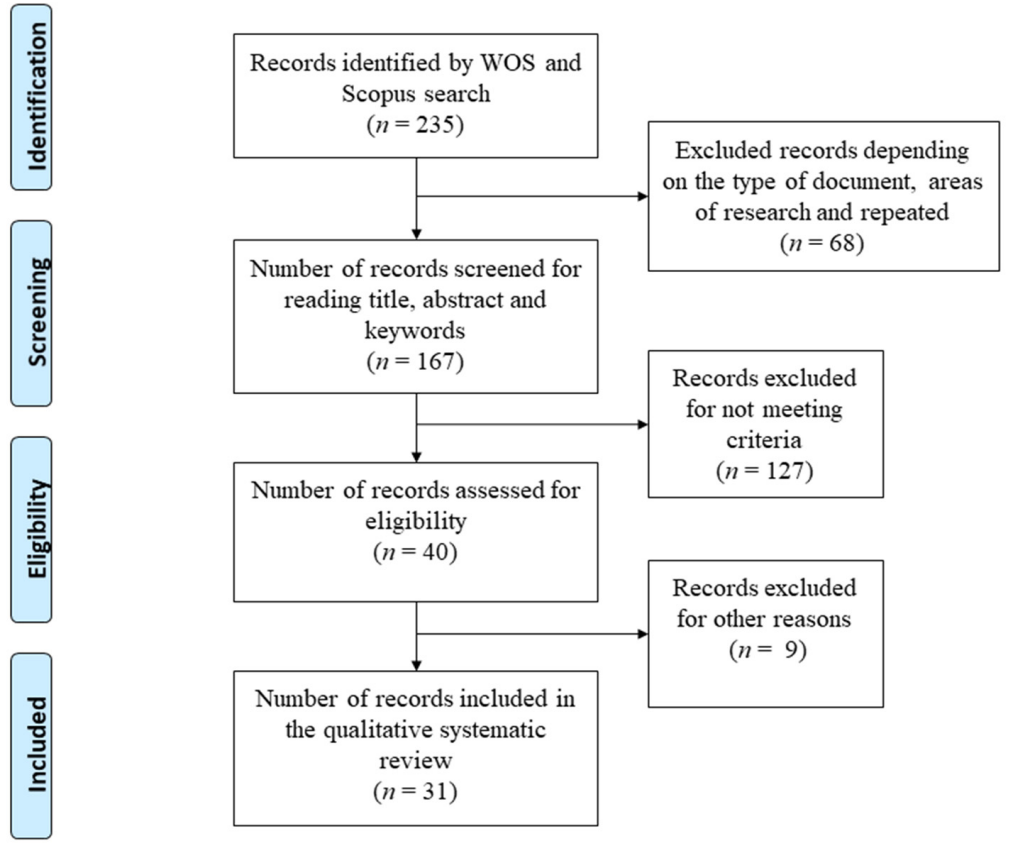

Figure 1. Flowchart of research paper selection.

\subsection{Data Collection Process}

To organise the findings of eligible papers, a data extraction form was developed and tested on a sample of included studies $(n=31)$. Data collection was done by the first author and reviewed again by the second author. For any discrepancies, the authors had a discussion to reach a consensus. Two tables (Tables 1 and 2) were created by recording and coding the following data for each eligible paper: Table 1: (1) paper; (2) authors; (3) year of the studies; (4) country; (5) age of children and adults observed and interviewed; (6) sample; (7) park type; (8) context. Table 2 presents data for (1) study objective; (2) study type; (3) variables analysed in the study; (4) data collection instruments; (5) conclusion. 
Table 1. Data related to the selected studies.

\begin{tabular}{|c|c|c|c|c|c|c|c|}
\hline Papers & Authors & Year & Country & Age & Sample * & Park Type ** & Context $* * *$ \\
\hline 1 & Flowers et al. [49] & 2020 & Australia & $3-11$ & $\begin{array}{c}86 \mathrm{Ch}(47 \mathrm{Ml} ; 39 \mathrm{Fm}) \\
571 \mathrm{~Pa}\end{array}$ & UP & H-M-L \\
\hline 2 & Veitch et al. [57] & 2020 & Australia & $8-12$ & $\begin{array}{c}30 \mathrm{Ch}(53 \% \mathrm{Fm}) \\
9 \mathrm{Pk}\end{array}$ & UP & H-M-L \\
\hline 3 & Flowers et al. [60] & 2019 & Australia & $3-11$ & $\begin{array}{l}375 \mathrm{~Pa} \\
317 \mathrm{Pk}\end{array}$ & UP & H-M-L \\
\hline 4 & Gil- Madrona et al. [61] & 2019 & Spain & $24-40$ & $\begin{array}{l}1.029 \mathrm{Ad} \\
41 \mathrm{Pk}\end{array}$ & UP & H-M-L \\
\hline 5 & Lal et al. [62] & 2019 & Australia & - & $2 \mathrm{Pk}$ & TUP vs. RUP & $\mathrm{L}$ \\
\hline 6 & Marquet et al. [63] & 2019 & USA & $5-10$ & $\begin{array}{l}16.577 \mathrm{Ch} \\
120 \mathrm{Pk}\end{array}$ & TUP & $\mathrm{L}$ \\
\hline 7 & Parra et al. [64] & 2019 & USA & - & $\begin{array}{c}599 \mathrm{Ad} ; 246 \mathrm{Ch} \\
1 \mathrm{Pk}\end{array}$ & TP (RUP) & M \\
\hline 8 & Quiao [65] & 2019 & China & $3-9 ; 24-40$ & 1.320 (1030 Ad; $290 \mathrm{Ch})$ & PR & H-M-L \\
\hline 9 & Talarowski et al. [53] & 2019 & London and USA & - & $16 \mathrm{Pk}$ & TUP vs. RUP & H-M-L \\
\hline 10 & Washington et al. [66] & 2019 & Australia & $18-60+$ & $\begin{array}{c}386 \mathrm{U}(61 \% \mathrm{Fm}) \\
12 \mathrm{Pk}\end{array}$ & TUP & - \\
\hline 11 & Adams, Veitch \& Barnett [67] & 2018 & Australia & $5-10$ & $\begin{array}{c}\text { 57(28 Fm; } 29 \mathrm{Ml}) \\
3 \mathrm{Pk}\end{array}$ & TUP-RUP-AP & - \\
\hline 12 & Rossi et al. [68] & 2018 & Brazil & $7-14$ & $2.152(56.5 \% \mathrm{Fm} ; 43.5 \% \mathrm{Ml})$ & $\mathrm{PP} / \mathrm{PR}$ & H-M-L \\
\hline 13 & Veitch et al. [69] & 2018 & Australia & $1-12$ & $\begin{array}{c}2374(49.6 \% \mathrm{Fm} ; 50.4 \% \mathrm{Ml}) \\
2 \mathrm{Pk}\end{array}$ & TUP vs. RUP & - \\
\hline 14 & Bezold et al. [70] & 2017 & USA & $11-14$ & $94.997 \mathrm{Ch}$ & $\mathrm{PP} / \mathrm{PR}$ & H-M-L \\
\hline 15 & Kaymaz, Oguz, \& Cengiz-Hergul [47] & 2017 & Turkey & $6-12$ & $\begin{array}{c}418 \mathrm{Ch} ; 383 \mathrm{~Pa} \\
8 \mathrm{Pk}\end{array}$ & UP & $\mathrm{M}-\mathrm{H}$ \\
\hline 16 & McCarthy, Hughey \& Kaczynski [71] & 2017 & USA & $8-11$ & $\begin{array}{l}13.469 \mathrm{Ch} \\
95 \mathrm{Pk}\end{array}$ & PR & $\mathrm{L}$ \\
\hline 17 & Ou, J.Y. et al. [51] & 2016 & USA & $\geq 18$ & $354 \mathrm{U}$ & UP & M-L \\
\hline 18 & Boonzajer et al. [4] & 2016 & The Netherlands & $0-15$ & $20 \mathrm{Pk}$ & RKF & $\mathrm{L}$ \\
\hline
\end{tabular}


Table 1. Cont.

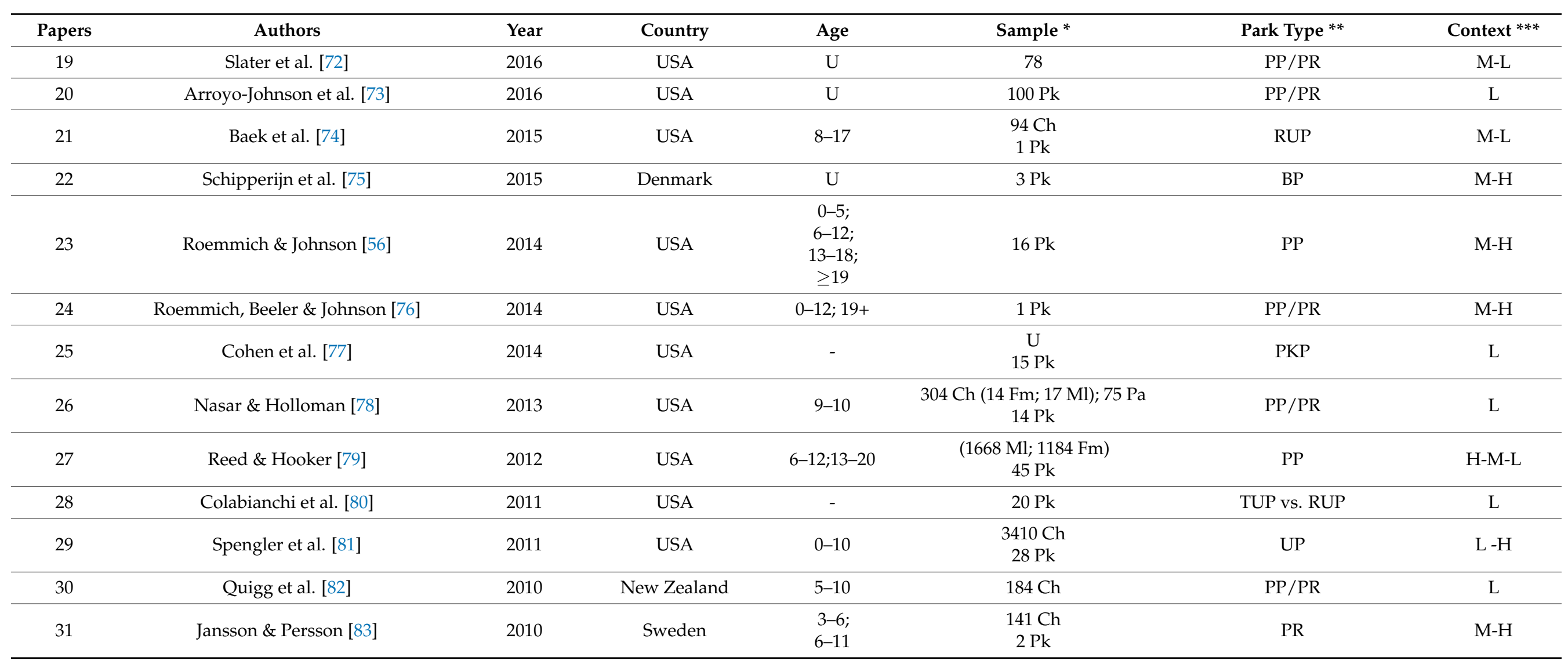

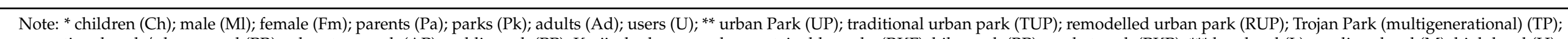

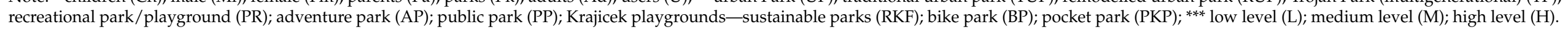


Table 2. Data related to the selected studies.

\begin{tabular}{|c|c|c|c|c|c|}
\hline No. & Study Objective & $S t^{*}$ & Variables & Instruments ** & Conclusions \\
\hline 1 & $\begin{array}{l}\text { To identify the type of children who visit parks far } \\
\text { from their homes and compare them with those } \\
\text { who do not visit. }\end{array}$ & QT & $\begin{array}{l}\text { Park size; distance; access } \\
\text { (transport); areas for activity; } \\
\text { quality and safety }\end{array}$ & $\begin{array}{l}\text { Interviews; ad-hoc } \\
\text { questionnaires; Google } \\
\text { maps; VPA }\end{array}$ & $\begin{array}{l}\text { Children and families are willing to travel further to visit larger } \\
\text { parks with a variety of facilities and services (sports courts, } \\
\text { bathrooms, water fountains, barbecues, picnic shelters...). }\end{array}$ \\
\hline 2 & $\begin{array}{l}\text { To identify the opinions of children from different } \\
\text { social classes regarding the characteristics that } \\
\text { influence their visits to the park, PA engagement } \\
\text { in the park and social interaction. }\end{array}$ & QL & $\begin{array}{l}\text { Visit frequency; time of } \mathrm{PA} ; \\
\text { social interaction }\end{array}$ & $\begin{array}{l}\text { Interviews; ad-hoc } \\
\text { questionnaires }\end{array}$ & $\begin{array}{l}\text { Children are attracted to parks that facilitate play, have } \\
\text { elements of risk/adventure and are large enough to allow for a } \\
\text { variety of physical and social activities. }\end{array}$ \\
\hline 4 & $\begin{array}{c}\text { To examine parents' perceptions of the } \\
\text { contribution of public parks to children's motor, } \\
\text { social and creative development and to reducing } \\
\text { childhood obesity. }\end{array}$ & QT & $\begin{array}{l}\text { Social skills, motor skills and } \\
\text { perceptual-motor skills; } \\
\text { creativity; obesity; sex and } \\
\text { age; educational level and } \\
\text { responsibility }\end{array}$ & Validated questionnaire & $\begin{array}{l}\text { Women between the ages of } 30 \text { and } 49 \text {, with high levels of } \\
\text { education and high levels of participation in their children's } \\
\text { education, had more positive perceptions of the impact of } \\
\text { public parks on children's motor, social and creative } \\
\text { development and the reduction of obesity in children. }\end{array}$ \\
\hline 5 & $\begin{array}{l}\text { To evaluate the profitability of installing an active } \\
\text { playground in a large park in a low } \\
\text { socio-economic area. }\end{array}$ & QT & $\begin{array}{l}\text { Time spent engaged in PA; } \\
\text { age; activity type; PA level }\end{array}$ & SOPARC; MET & $\begin{array}{l}\text { The remodelling of the park, designed specifically for children, } \\
\text { was effective in increasing their PA. }\end{array}$ \\
\hline 6 & $\begin{array}{l}\text { To examine the association between the } \\
\text { characteristics of the park and its use by } 5-10 \text { year } \\
\text { olds of different ethnicities }\end{array}$ & QT & $\begin{array}{l}\text { Park characteristics and the } \\
\text { use of different areas; age; } \\
\text { race; activity type; PA level }\end{array}$ & SOPARC; MET & $\begin{array}{c}\text { Significant associations were found between park use, PA } \\
\text { levels and park area characteristics. }\end{array}$ \\
\hline 7 & $\begin{array}{c}\text { To investigate park use, and satisfaction and } \\
\text { perceptions of park users regarding park } \\
\text { improvements. }\end{array}$ & QT & $\begin{array}{l}\text { Park use and characteristics } \\
\text { of different areas; age; activity } \\
\text { type; PA level }\end{array}$ & $\begin{array}{l}\text { Intercept interviews; } \\
\text { video; SOPARC }\end{array}$ & $\begin{array}{l}\text { Multi-generational parks with access to various activities and } \\
\text { fitness areas facilitate PA in different age groups and can } \\
\text { provide social and physical health benefits. }\end{array}$ \\
\hline 8 & $\begin{array}{l}\text { To identify the preferences of parents of children } \\
(3-9 \text { years) in terms of the availability, location, } \\
\text { shape, characteristics, safety and comfort of parks. }\end{array}$ & QT & $\begin{array}{l}\text { Location; design; operational } \\
\text { characteristics; safety and } \\
\text { comfort }\end{array}$ & Online survey & $\begin{array}{l}\text { Preference is given to playgrounds that are close to home or } \\
\text { playgrounds in central green residential areas which offer the } \\
\text { possibility of outdoor activity, green areas and high levels } \\
\text { of safety. }\end{array}$ \\
\hline 9 & $\begin{array}{l}\text { To compare and evaluate playground use and } \\
\text { levels of moderate to vigorous PA in innovative } \\
\text { versus traditional playgrounds. }\end{array}$ & QT & Park use; PA level & SOPARC; Video & $\begin{array}{l}\text { The design of an innovative playground was associated with } \\
\text { an increase in MVPA, however, playground size was more } \\
\text { strongly associated with the number of visitors. }\end{array}$ \\
\hline
\end{tabular}


Table 2. Cont.

\begin{tabular}{|c|c|c|c|c|c|}
\hline No. & Study Objective & St $*$ & Variables & Instruments ** & Conclusions \\
\hline 10 & $\begin{array}{l}\text { To learn about the use of public parks in } \\
\text { residential areas and the social interactions that } \\
\text { take place in this context. }\end{array}$ & QL & $\begin{array}{l}\text { Use; park design; type and } \\
\text { level of PA; social interaction }\end{array}$ & $\begin{array}{l}\text { Ad-hoc questionnaire } \\
\text { Intercept interviews }\end{array}$ & $\begin{array}{l}\text { Public parks in residential neighborhoods were proven to be } \\
\text { specific areas for PA and social engagement. }\end{array}$ \\
\hline 12 & $\begin{array}{l}\text { To study the relationship between the use of } \\
\text { public places for PA and active leisure with } \\
\text { respect to distance and overweight/obesity } \\
\text { indicators in school children from different areas. }\end{array}$ & QT & $\begin{array}{l}\text { Distance; frequency of use; } \\
\text { body mass index (BMI); waist } \\
\text { circumference (WC) }\end{array}$ & Questionnaire & $\begin{array}{l}\text { Living closer to parks/playgrounds was associated with lower } \\
\text { BMI and waist circumference amongst school children from } \\
\text { low-income families. }\end{array}$ \\
\hline 13 & $\begin{array}{l}\text { To evaluate the impact of a playground facility on } \\
\text { park visits and physical activity engagement } \\
\text { within the park. }\end{array}$ & QT & Frequency of use; PA levels & $\begin{array}{l}\text { SOPARC; intercept } \\
\text { interviews; objective } \\
\text { monitoring }\end{array}$ & $\begin{array}{l}\text { A well-designed playground facility can increase the number } \\
\text { of visits to parks and PA engagement in children aged } \\
\qquad 1-12 \text { years. }\end{array}$ \\
\hline 14 & $\begin{array}{l}\text { To assess whether increases in the density of } \\
\text { parks, playgrounds and sports facilities in the } \\
\text { surrounding areas of a school are related with } \\
\text { improvements in school physical fitness. }\end{array}$ & QT & $\begin{array}{l}\text { Density of parks, } \\
\text { playgrounds and sports } \\
\text { facilities; physical fitness } \\
\text { levels }\end{array}$ & $\begin{array}{l}\text { Built Environment \& } \\
\text { Health Research Group } \\
\text { (Columbia Un) } \\
\text { FITNESSGRAM Test }\end{array}$ & $\begin{array}{l}\text { No clear patterns of association were observed between the } \\
\text { density of recreational resources around the school and } \\
\text { changes in the physical condition of students. }\end{array}$ \\
\hline 15 & $\begin{array}{l}\text { To investigate patterns and factors related with } \\
\text { the green space use behaviours of children aged } \\
6-12 \text { years and their parents. }\end{array}$ & QT/QL & $\begin{array}{l}\text { Parental leisure trends; green } \\
\text { area use }\end{array}$ & $\begin{array}{l}\text { Ad-hoc questionnaire; } \\
\text { drawing and/or writing } \\
\text { surveys; questionnaire }\end{array}$ & $\begin{array}{l}\text { Children's use of green spaces is strongly linked to the } \\
\text { environmental attitudes of their parents and the characteristics } \\
\text { of their physical environment. }\end{array}$ \\
\hline 16 & $\begin{array}{l}\text { To examine disparities in access and quality of } \\
\text { play areas according to socio-demographic } \\
\text { characteristics, and examine associations between } \\
\text { access and quality of play areas and BMI. }\end{array}$ & QT & $\begin{array}{l}\text { Access to playgrounds; } \\
\text { playground quality; gender; } \\
\text { race/ethnicity; } \\
\text { socioeconomic status; BMI }\end{array}$ & $\begin{array}{l}\text { GIS shapefiles; ArcGIS } \\
\text { 10.2; CPAT }\end{array}$ & $\begin{array}{l}\text { Children with lower quality play areas were more likely to be } \\
\text { overweight than children without access to play areas. There } \\
\text { were no significant outcomes regarding access/quality and } \\
\text { weight as a function of economic status. }\end{array}$ \\
\hline 17 & $\begin{array}{c}\text { To investigate park use and PA engagement, and } \\
\text { the relationship of this with exposure to } \\
\text { community violence }\end{array}$ & QT & $\begin{array}{l}\text { Age; sex; race/ethnicity; } \\
\text { education; injury; } \\
\text { employment status; } \\
\text { seasonality }\end{array}$ & Questionnaire & $\begin{array}{l}\text { Users prefer parks with a variety of facilities, green spaces and } \\
\text { walking trails. Insecurity decreased all types of PA. }\end{array}$ \\
\hline 18 & $\begin{array}{l}\text { To examine whether park use and PA level in } \\
\text { children is higher in Krajicek playgrounds } \\
\text { compared with control playgrounds. }\end{array}$ & QT & Park use; PA level & $\begin{array}{l}\text { Direct observation; } \\
\quad \text { SOPLAY }\end{array}$ & $\begin{array}{l}\text { The study shows that children's park use and PA level are } \\
\text { higher in Krajicek playgrounds than in control playgrounds in } \\
\text { disadvantaged neighbourhoods. }\end{array}$ \\
\hline
\end{tabular}


Table 2. Cont.

\begin{tabular}{|c|c|c|c|c|c|}
\hline No. & Study Objective & $\mathrm{St}^{*}$ & Variables & Instruments ** & Conclusions \\
\hline 19 & $\begin{array}{l}\text { To compare park use and PA outcomes between a } \\
\text { renovated playground that is adapted to the } \\
\text { community and non-renovated parks. }\end{array}$ & QT & $\begin{array}{l}\text { Park use and PA level; } \\
\text { neighbourhood safety; } \\
\text { distance to the park and } \\
\text { climate }\end{array}$ & SOPARC & $\begin{array}{l}\text { Involving the community in playground renovations can have } \\
\text { a positive effect on park use and the intensity of the PA } \\
\text { engaged in. }\end{array}$ \\
\hline 20 & $\begin{array}{l}\text { To assess the impact of playground safety and } \\
\text { distance as part of the built environment on } \\
\text { increased youth PA. }\end{array}$ & QT & Safety; maintenance; distance & Surveys; Google Earth & $\begin{array}{l}\text { Disparities in playground safety and proximity reveal an } \\
\text { opportunity to develop community-wide playground } \\
\text { interventions for PA in youth. }\end{array}$ \\
\hline 22 & $\begin{array}{l}\text { To evaluate park use and PA levels of users of } \\
\text { three new bicycle parks. }\end{array}$ & QT/QL & Park use; PA levels; time zone & $\begin{array}{l}\text { SOPARC; on-site } \\
\text { interviews }\end{array}$ & $\begin{array}{l}\text { Park use and active participation of children and adolescents } \\
\text { increased, particularly amongst boys; } 63 \% \text { of users were active } \\
\text { during use. }\end{array}$ \\
\hline 23 & $\begin{array}{l}\text { To determine seasonal variation in park visits, the } \\
\text { choice of services and PA intensity. }\end{array}$ & QT & $\begin{array}{l}\text { Park use; age; sex, PA levels; } \\
\text { heat sensation }\end{array}$ & SOPARC & $\begin{array}{l}\begin{array}{l}\text { Less total PA was engaged in during winter than during other } \\
\text { seasons. }\end{array}\end{array}$ \\
\hline 24 & $\begin{array}{l}\text { To examine the effects of an intervention based on } \\
\text { the removal of seating on the time spent using the } \\
\text { park and PA improvement. }\end{array}$ & QT & Park use; age; sex; PA levels & SOPARC & $\begin{array}{l}\text { Adults were more physically active. Curtailing of the time } \\
\text { made available to children to use and play in the park was } \\
\text { reduced. }\end{array}$ \\
\hline 25 & $\begin{array}{l}\text { To assess the use of new pocket parks in } \\
\text { low-income neighbourhoods. }\end{array}$ & QT & $\begin{array}{l}\text { Age; sex; race/ethnicity; PA } \\
\text { levels; park characteristics. }\end{array}$ & SOPARC; surveys & $\begin{array}{l}\text { Pocket parks are perceived to be attractive and safe } \\
\text { destinations and may increase PA by encouraging families to } \\
\text { walk there with their children. }\end{array}$ \\
\hline 26 & $\begin{array}{l}\text { To uncover the main characteristics influencing } \\
\text { the choice of playgrounds in African-American } \\
\text { children and their parents. }\end{array}$ & QT & Park characteristics; park use & Survey; adapted SOPARC & $\begin{array}{l}\text { Outcomes verified correlations between park suitability and } \\
\text { provision of good quality and safe equipment. }\end{array}$ \\
\hline 27 & $\begin{array}{l}\text { To identify the most used areas of the park for PA } \\
\text { and PA levels in children in } 45 \text { parks in a } \\
\text { south-eastern community. }\end{array}$ & QT & $\begin{array}{l}\text { Park use, Age; sex; } \\
\text { race/ethnicity; PA level }\end{array}$ & SOPARC & $\begin{array}{c}\text { The swing areas was the most used active setting by children, } \\
\text { regardless of ethnicity. }\end{array}$ \\
\hline 28 & $\begin{array}{l}\text { To examine the influence of park or playground } \\
\text { characteristics such as the amount, type and } \\
\text { safety of equipment on park/playground use and } \\
\text { PA level. }\end{array}$ & QT & $\begin{array}{l}\text { Park characteristics; } \\
\text { socioeconomic status; PA } \\
\text { level }\end{array}$ & $\begin{array}{l}\text { Environmental } \\
\text { Assessment of Public } \\
\text { Recreation Space } \\
\text { Systematic Observation }\end{array}$ & $\begin{array}{l}\text { The total number of features or amenities in the } \\
\text { park/ playground is associated with the use of renovated } \\
\text { parks/playgrounds but not with PA levels. }\end{array}$ \\
\hline
\end{tabular}


Table 2. Cont.

\begin{tabular}{|c|c|c|c|c|c|}
\hline No. & Study Objective & $\mathrm{St}^{*}$ & Variables & Instruments ** & Conclusions \\
\hline 29 & $\begin{array}{l}\text { To examine the PA levels in children in } \\
\text { neighbourhood parks. }\end{array}$ & QT & $\begin{array}{l}\text { Sex; race/ethnicity; } \\
\text { neighbourhood income level; } \\
\text { amount of shade; time of day; } \\
\text { organised activity; park } \\
\text { activity areas }\end{array}$ & SOPLAY; & $\begin{array}{c}\text { Children's PA engagement in parks in high-income } \\
\text { neighbourhoods was higher than that of those in lower } \\
\text { income areas. } \\
\text { To increase PA, parks should provide courts, playgrounds and } \\
\text { free play areas. }\end{array}$ \\
\hline 30 & $\begin{array}{l}\text { To identify the proportion of children's PA that } \\
\text { occurs in public parks with play areas. }\end{array}$ & QT & PA level; height; weight & $\begin{array}{l}\text { Actigraph GT1M; } \\
\text { Globalsat DG-100 }\end{array}$ & $\begin{array}{l}\text { A low proportion of children's PA activity engagement occurs } \\
\text { in parks with play areas (only } 2 \% \text { of total daily PA). }\end{array}$ \\
\hline 31 & $\begin{array}{l}\text { To assess whether the existing offer of traditional } \\
\text { parks is adapted to the needs and preferences of } \\
\text { different users. }\end{array}$ & QL/QT & $\begin{array}{l}\text { Park characteristics; use and } \\
\text { preferences; play areas and } \\
\text { equipment }\end{array}$ & $\begin{array}{l}\text { Questionnaire; interview; } \\
\text { observation; GIS mapping } \\
\text { technique }\end{array}$ & $\begin{array}{l}\text { Users have different needs and preferences as a function of } \\
\text { their age. The planning and management of playgrounds } \\
\text { should take greater consideration of the needs of users and the } \\
\text { local context. }\end{array}$ \\
\hline
\end{tabular}

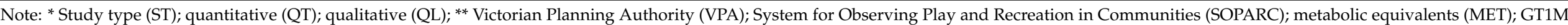

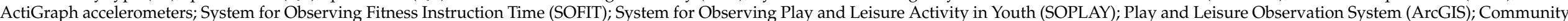
Park Audit Tool (CPAT). 


\subsection{Risk of Bias in Studies}

This study was coded by two of the authors in order to verify the reliability of the coding and the degree of agreement between the investigators for the selection and extraction of the data [84]. The risk of bias of each eligible article was assessed by adopting a dichotomous nominal scale of two unique values (yes/no), which was developed to assess concordance in the 31 studies in the sample. As variables of the scale, the inclusion and exclusion criteria indicated in Section 2.1 were taken (eligibility criteria). The degree of agreement obtained in the classification of the papers was $93 \%$, which was obtained by dividing the number of coincidences by the total number of categories defined for each study and multiplying it by 100 .

\section{Results}

\subsection{Study Selection}

As shown in Figure 1, a total of 235 papers were identified from the electronic databases WOS and SCOPUS, 195 of which were discarded after the evaluation of the abstracts, and the eligibility of the full texts of the 40 papers remaining was examined. Finally, 31 papers were selected and extracted, in which a total of 131,607 children (0 to 17 years) and 3526 adults (18 years and older) participated, and 1046 parks had been analysed.

\subsection{Characteristics of Eligible Studies}

\subsubsection{Outcomes Pertaining to Park Type}

Following analysis of the articles obtained, it can be seen that $32.5 \%(n=10)$ of studied parks (Table 3) corresponded to traditional urban parks; 35.48\% $(n=11)$ were focused on children's parks (playground) and the remaining 32.25\% $(n=10)$ consisted of remodelled, innovative, contemporary and sustainable parks with special characteristics.

Table 3. Types of parks analysed.

\begin{tabular}{|c|c|c|c|c|}
\hline & Park Type & & Number of Papers & Percentage \\
\hline & Parks (urban, traditional) & & 10 & $32.25 \%$ \\
\hline & Recreational parks (playground) & & 11 & $35.48 \%$ \\
\hline \multirow{5}{*}{ Other } & Remodelled & 2 & \multirow{5}{*}{10} & \multirow{5}{*}{$32.25 \%$} \\
\hline & Innovative & 2 & & \\
\hline & Sustainable park & 1 & & \\
\hline & Contemporary & 1 & & \\
\hline & $\begin{array}{l}\text { Special: Bike park, pocket park, } \\
\text { adventure park, Trojan Park }\end{array}$ & 4 & & \\
\hline
\end{tabular}

\subsubsection{Outcomes Pertaining to the Socio-Economic Context}

Based on the classification on the economic context found in most of the papers in the sample, three categories were distinguished: high, medium and low socioeconomic levels. In those studies in which the socioeconomic level of the park's users was not specifically specified, data such as the poverty index, GDP and unemployment rate of the city, region or state where the parks were located were reviewed.

As can be seen in Table 4, almost 39\% of included studies were carried out in mediumlow socio-economic contexts, whilst around $30 \%$ focused on plural contexts which covered all socio-economic categories. Only $19.35 \%$ of considered research was directed towards upper-middle class users. 
Table 4. Socioeconomic context.

\begin{tabular}{|c|c|c|c|c|}
\hline \multicolumn{3}{|c|}{ Socioeconomic Context: } & Number of Papers & Percentage \\
\hline \multicolumn{3}{|c|}{ All: Low, medium, high } & 9 & $29.03 \%$ \\
\hline \multirow{2}{*}{ High } & Medium-high & 5 & \multirow{2}{*}{6} & \multirow{2}{*}{$19.35 \%$} \\
\hline & Medium & 1 & & \\
\hline \multirow{2}{*}{ Low } & Medium-low & 2 & \multirow{2}{*}{12} & \multirow{2}{*}{$38.70 \%$} \\
\hline & Low & 10 & & \\
\hline \multicolumn{3}{|c|}{ Unspecified } & 4 & $12.90 \%$ \\
\hline
\end{tabular}

\subsubsection{Outcomes Pertaining to Analysed Variables}

The most commonly considered variables in the 31 studies (Table 5) corresponded to the "park characteristics" group, with the variable "characteristics of the park" / "equipment" / "design" being particularly prevalent, appearing in 14 papers (45.16\%). Variables referring to PA were also considered by a large number of papers, for example the variables "physical activity intensity" and "physical activity levels" which accounted for $54 \%$ of the total $(n=17)$.

Table 5. Variables examined in the considered research articles.

\begin{tabular}{cccc}
\hline & Variables & $\begin{array}{c}\text { Number of Papers to } \\
\text { Include This Variable }\end{array}$ & Percentage \\
\hline $\begin{array}{c}\text { Pertaining to } \\
\text { features of the } \\
\text { park }\end{array}$ & Features/equipment/quality/design & 14 & $45.16 \%$ \\
\hline \multirow{3}{*}{$\begin{array}{c}\text { Security } \\
\text { Pertaining to }\end{array}$} & Access/location/distance & 6 & $19.35 \%$ \\
park use & Frequency/number/density & 8 & $25.80 \%$ \\
\hline & Activity zones & 15 & $48.38 \%$ \\
Pertaining to & Time of day & 5 & $16.12 \%$ \\
PA & Weather & 2 & $6.45 \%$ \\
& PA time & 2 & $6.45 \%$ \\
\hline & PA type & 1 & $3.22 \%$ \\
Pertaining to & Motor skills & 8 & $25.80 \%$ \\
users & Age/gender & 17 & $54.83 \%$ \\
& Ethnicity & 13 & $6.45 \%$ \\
\hline
\end{tabular}

Within the group relating to park use, the variables "frequency", "number" or "density" should also be mentioned, amounting to $48.38 \%(n=15)$ of all considered variables.

With regards to park users, inclusion of the variables "age" and "sex" on 13 occasions was notable, as was the inclusion of "ethnicity" by seven papers (all in the USA).

\subsubsection{Outcomes Pertaining to Employed Instruments}

Among the instruments used, we found that $70 \%$ of the 31 papers analysed used questionnaires, surveys or interviews. In addition, more than half (51.61\%) used observation techniques, the most important of which was the System for Observing Play and Recreation in Communities (SOPARC) (12 papers). Almost 30\% of the research studies utilised some type of instrument related to the location and density of parks. Only one study carried out a physical fitness test (Table 6). 
Table 6. Frequency of instrument use.

\begin{tabular}{|c|c|c|}
\hline Instrument & Number of Papers & Percentage \\
\hline Surveys & 6 & $19.35 \%$ \\
\hline Questionnaires (ad hoc and validated) & 9 & $29.03 \%$ \\
\hline Interviews & 8 & $25.80 \%$ \\
\hline Bespoke pen and paper audit tool & 1 & $3.22 \%$ \\
\hline $\begin{array}{l}\text { Environmental Assessment of Public } \\
\text { Recreation Space } \\
\text { Systematic Observation (EAPRS) }\end{array}$ & 1 & $3.22 \%$ \\
\hline Field observation & 2 & $6.45 \%$ \\
\hline SOPARC & 12 & $38.70 \%$ \\
\hline SOFIT & 1 & $3.22 \%$ \\
\hline SOPLAY & 2 & $6.45 \%$ \\
\hline GOOGLE MAP & 2 & $6.45 \%$ \\
\hline Mapping GSI & 1 & $3.22 \%$ \\
\hline GOOGLE EARTH & 1 & $3.22 \%$ \\
\hline ArcGIS 10.2; 9.0 & 2 & $6.45 \%$ \\
\hline RECEPTOR GPS (DNR Garmin Foretrex 201) & 1 & $3.22 \%$ \\
\hline Global Positioning System: Globals DG-100 & 1 & $3.22 \%$ \\
\hline TRAIL MONITORS & 1 & $3.22 \%$ \\
\hline MET & 2 & $6.45 \%$ \\
\hline ActiGraph accelerometers GT1M & 3 & $9.67 \%$ \\
\hline TEST FITNESSGRAM & 1 & $3.22 \%$ \\
\hline
\end{tabular}

\subsubsection{Outcomes Pertaining to Study Objectives}

In the 31 papers analysed (Table 7$)$, we found that $83.87 \%(n=26)$ had a main aim that was directly or indirectly related to park design.

Five papers $(16.12 \%)$ were not related to park design. Instead, they focused on the observation of physical activity engagement in parks, seasonal park use, parental perceptions with regards to their children's motor development and positive implications for obesity, park use from the perspective of the intergenerational relationships they cause, and the relationship between the number of parks and obesity.

\subsection{Synthesis of the Reviewed Studies}

As a synthesis of the data analysed in the previous section, we highlight that the variables most analysed in the 31 studies correspond to the park use group, shown in a total of 19 papers $(61.3 \%)$ : the characteristics of the park $(n=15 ; 48.4 \%)$, the perceptions of users, both children and adults $(n=9 ; 29 \%)$, the time of PA $(n=6 ; 19.4 \%)$ and the intensity of PA $(n=13 ; 41.9 \%)$. The data collection instruments for each block of variables were varied, with the following being predominant:

- Use of the park: Of the 19 papers that measured this variable, the most used instruments were the SOPARC $(n=11 ; 57.9 \%)$, interview $(n=5 ; 16.1 \%)$ and questionnaires $(n=4 ; 12.9 \%)$.

- Characteristics of the park: Of the 15 papers that analysed different characteristics, the most widely used instruments were questionnaires $(n=6 ; 40 \%)$ and SOPARC $(n=4$; 26.7\%).

- $\quad$ Perceptions of users, both children and adults: Out of nine papers, the most used instruments were interviews and questionnaires $(n=4 ; 44.4 \%)$, which were used in each of them. 
- PA time: Of the six papers that analysed this variable, the most widely used instruments were the SOPARC $(n=3 ; 50 \%)$ and the MET-h $(n=2 ; 33.3 \%)$.

- PA intensity: Of the 13 papers that measured it, the most used instrument was the SOPARC $(n=11 ; 84.6 \%)$ and the SOPLAY and accelerometers, with $(n=3 ; 23.1 \%)$ each.

Table 7. Research objectives.

\begin{tabular}{|c|c|c|c|c|}
\hline Study Categories & Number of Papers & Percentage & Objectives & Number of Papers \\
\hline \multirow{6}{*}{ Related to DESIGN } & \multirow{6}{*}{26} & \multirow{6}{*}{$83.87 \%$} & $\begin{array}{c}\text { Park characteristics/park design and } \\
\text { use/PA increases }\end{array}$ & 12 \\
\hline & & & $\begin{array}{l}\text { Comparison: traditional vs. renovated } \\
\text { parks }\end{array}$ & 2 \\
\hline & & & Remodelling/intervention effects & 5 \\
\hline & & & Impact of special parks & 2 \\
\hline & & & $\begin{array}{l}\text { Distance and park use } \\
\text { Access and obesity }\end{array}$ & 3 \\
\hline & & & $\begin{array}{l}\text { Security and access } \\
\text { PA level and violence }\end{array}$ & 2 \\
\hline \multirow{5}{*}{$\begin{array}{l}\text { OTHER not related } \\
\text { to design }\end{array}$} & \multirow{5}{*}{5} & \multirow{5}{*}{$16.12 \%$} & PA engagement in parks & 1 \\
\hline & & & Park use as a function of seasonal effects & 1 \\
\hline & & & $\begin{array}{l}\text { Parental perceptions regarding their } \\
\text { children's motor development and the } \\
\text { reduction of obesity }\end{array}$ & 1 \\
\hline & & & $\begin{array}{l}\text { The construction of intergenerational } \\
\text { relationships as a result of park use }\end{array}$ & 1 \\
\hline & & & $\begin{array}{l}\text { The relationship between the number of } \\
\text { parks and obesity }\end{array}$ & 1 \\
\hline
\end{tabular}

Of the sample object of this study $(n=31), 48.38 \%(n=15)$ of the papers established a direct relationship between the design, characteristics and equipment of the park with an increase in visits, a greater and more effective use of the park, and a greater intensity of PA, with $32.25 \%(n=10)$ being remodelled, innovative, contemporary and sustainable parks with special characteristics $[4,53,62,64,69,72,75,77,80]$. If the needs of users are also taken into account in the remodelling or design of new parks, $16.12 \%(n=5)$ of the studies analysed concluded that it can create a positive effect on the number of visitors and, therefore, an increase in PA performed $[49,66,71,83]$. Regarding the characteristics that parks should have to encourage visits and their use, of $n=12(38.7 \%)$ papers that addressed the age from three to six years, the main characteristics that were considered relevant in a park, according to the perceptions of the children's companions, were: a safe environment $(41.7 \%)$ that allows outdoor activity $(25 \%)$, has green areas and forests $(25 \%)$, close to their residence $(25 \%)$, allows various activities $(16.7 \%)$ and has swings $(16.7 \%)$.

Of $n=9(29 \%)$ papers that addressed the age of 6-12 years, the main characteristics that were considered relevant according to the perceptions of the children's companions were: a safe environment $(44.4 \%)$ with green areas and forests $(44.4 \%)$ that have a variety of facilities and allow various activities (44.4\%) and that have comfort zones (22.2\%).

According to the perspective of the 6 to 12 -year-old children themselves, in $n=2(6.5 \%)$ papers found, we observed that their preferences were focused on large parks, selecting a variety of activities and having comfort zones.

From the point of view of the increase in visits and use of the park, according to observational studies of $n=12(38.7 \%)$ papers that addressed the age of 3-6 years, the main characteristics that were considered relevant were: a variety of games and activities (33.3\%), swings $(33.3 \%)$, green areas $(16.7 \%)$ and that they are well designed, even if the park is 
further away from their area residential (16.7\%). However, of $n=9(29 \%)$ papers covering the ages of 6 to 12 years, the observational studies highlighted important characteristics: the variety of play areas (55.6\%), which allow for organised sports $(44.4 \%)$ and that have green areas $(22.2 \%)$.

Regarding the ability of parks to promote PA, of $n=7(22.6 \%)$ studies whose objective was to achieve an increase in physical activity in children, $100 \%$ of them obtained positive results. In total, $85.7 \%$ of these studies were related to renovations, creation of innovative parks and special parks. Of $n=10$ papers that measured the intensity of physical activity in children, $100 \%$ indicated an increase in moderate to vigorous intensity PA (MVPA); 66.7\% of these studies referred to models or special parks.

\subsection{Risk of Bias of the Studies}

To establish the methodological quality of the study, the reliability of selection and detection was determined by two authors using Cohen's Kappa statistical index (Kc). A value of $\mathrm{Kc}=0.834$ was obtained for the coding, which shows an acceptable concordance and was analysed using the statistical software IBM SPSS ${ }^{\circledR}$ in its version 24.0 (IBM Corp., Armonk, NY, USA) for Windows.

\section{Discussion}

\subsection{Evidence Summary}

Public parks have been proposed as an option for health promotion when it comes to addressing the high rates of physical inactivity [85] in the general population, and especially in children [23] from the earliest ages. This is because parks are considered to offer safe spaces for exercise and are available to the entire population [45]. Therefore, they have the potential to restore the health and well-being of users, especially in large cities where the physical environment favours a sedentary lifestyle and associated diseases [86]. This systematic review aimed to contribute to the need to expand data on the characteristics that parks and their surroundings should have to facilitate and maximise the practice of PA in them. This need is reflected in previous reviews such as those by Zhang et al. [87], where the inconsistency presented by the findings on the environmental factors of the park and the neighborhood was highlighted. This review provides data focused on the needs of school-age children (preschool stage, from 0 to 6 years old, and primary stage, from 7 to 12 years old), although the data provided from the selection of studies does not allow for taking into account differences according to gender. The data obtained are not highly consistent due to the scarcity and variety of studies and the lack of specific data focused on these stages. On the other hand, the review provides data related to the interests of park users, both children and the adults in charge of running them, establishing differences according to these age ranges and providing data from opinion studies, as well as observational and experimental studies. Finally, the characteristics of the different park designs that favour the increase in PA, its intensity and the development of motor skills are established.

Among the findings, we highlight that, although the socioeconomic contexts analysed have been varied, it is observed that children living in low-income communities have a higher risk of obesity due to the associated health inequalities [88]. However, this is not supported by the low percentage of studies included in the review. These populations are served by fewer services, which also tend to be of lower quality [89]. Therefore, a park renovation can benefit the PA of children living in these settings. Focusing efforts on the remodelling and/or design of parks in areas of low socioeconomic status is essential from the perspective of health and PA. This is because improving public spaces in disadvantaged areas can increase recreational PA $[4,62,64]$. This is not only beneficial for children from disadvantaged backgrounds, but it also applies to other contexts where, as current data indicate, park use is higher among boys than girls $[49,64,79]$. Therefore, the consideration of user preferences can improve the use of parks regardless of gender, although this should be studied in a more in-depth way since the sample selected in this review is not sufficient. 
Families and caregivers of children tend to agree on the positive contribution of public playgrounds to the development of social, motor, cognitive and physical skills [61]. Taking into account the opinions of local populations will allow for a better understanding and planning of park design, or if necessary, redesign. This will ensure optimal use at different ages and by all genders and will increase visits to the park, PA, development of motor skills, physical fitness and social interaction $[57,62,81]$. However, user opinions are often not taken into account, causing the parks to be underused [83] and attracting only a subset of neighborhood children [50].

The results of the analysed papers regarding to the perspectives of the users could be a starting point for new approaches directed to individual populations, depending on the social and economic context. However, less than half of the investigations considered included surveys or interviews to capture the opinions of users, whether they were adults (families or caregivers of children during leisure time) or the children themselves. In fact, only two studies specifically focused on the perceptions of children aged 7 to 12 years $[57,68]$. Qualitative research is important and provides a lot of data on park preferences from the users' point of view. This would allow a more effective adaptation of the parks for the improvement of PA $[49,51,57,66,71]$. Thus, we consider it to be an essential aspect for future research.

The main data emerging from the research, after considering the users and their age, are the following:

According to the opinion of family members and caregivers of children from 0 to 6 years old, to encourage greater use of these spaces, playgrounds should offer opportunities for outdoor activities with green areas and forests $[60,65,83]$, and be close to their residence or where their friends or relatives live $(60,65,81]$, as this will allow them to interact with other children or with their parents. Parks should allow the performance of various activities and games that motivate children $[60,69]$, with safety and cleanliness being another factor that encourages visits $[65,83]$. However, family members and caregivers aged 7 to 12 choose large parks (even if they are not located near their residential area) [60] and, with sports facilities and other amenities such as bathrooms, seats, fountains with drinking water, barbecues and gardens $[49,57,78]$. In addition, they must have areas that allow different age groups to exercise (multigenerational parks) [64], have different play areas [78], that are accessible [51,64,78], of high quality [83] and restrictions on dogs, vandalism, litter and fencing. This is in line with the review by Audrey and Batista-Ferrer [90] who stated that the provision of clean, safe and accessible public open spaces can offer opportunities for physical activity and social interaction, however, data obtained by Zhang et al. [87] did not find this to be a significant factor. Although most users of play areas prefer that the facilities are nearby, this is not a decisive characteristic when choosing a park [83], a fact that coincides with the findings obtained by Zhang et al. [87]. Parents' preference for parks farthest from their residence, but that are better equipped, is because they think that these types of parks are more suitable for the whole family. This is because many children of this age tend to have siblings, so they seek more opportunities for activities than those offered by nearby but small parks [49].

Regarding the data obtained about the motivations of children from 0 to 6 years old to attend the parks, we did not find any study that examined their perceptions, which indicates the need for studies at these ages.

This may be due to difficulties in administering reliable measuring instruments at these ages. However, in the following range (8-12 years), although only two papers were found that analysed opinions at these ages, they showed a preference towards large parks with green areas or forests for playing, cycling or sports [57,83]. Parks should include play equipment that involves some risk and adventure, such as swings and large and tall slides [57] and that have other facilities (seating and picnic areas) that allow for social interactions and a place to go with friends, siblings or adult relatives [57,83]. Contrary to what is believed by parents and children of other ages [91,92], these children are not concerned about the lack of comfort, safety or cleanliness [57]. 
Regarding the characteristics obtained in the observational and experimental studies carried out in different types of parks (remodelled, innovative, special and traditional), this study provides, as a novelty, the characteristics that must be taken into account in the remodelling and innovation processes of traditional parks or in the creation of new parks that favour their use. Thus, the data reflect that large swings, 360-degree traditional swings, mazes, rocking chairs, sandboxes, adventure equipment (for example, climbing equipment) and games in nature should be incorporated [62,69], and fitness areas should be created [64]. Garden areas with spaces for community events [74] should be added, and shaded areas and different play spaces [80] should be created to facilitate unstructured play [81]. In addition, according to Roemmich and Johnson [56], ice rinks, hills for tobogganing, crosscountry skiing and covered areas for physical activity should be provided and lighting improved to encourage active use of parks in colder areas during the winter.

These parks must also be safe to facilitate the practice of PA, especially when targeting women [51], and must have multigenerational accessibility [64]. The latter may be a key component for the more widespread adoption of healthy practices in urban parks. Differences are found between the different parks that children visit between the ages of 3 and 12 . As children transition from preschool age (3-5 years) to elementary school age (6-9 and 9-11 years), they visit larger, better-equipped parks with sports fields and recreational activities that are more adventurous and challenging [57]. Comfort also becomes more important for this group, as reflected in the need for comfort facilities such as bathrooms, better lighting, etc. [60].

Regarding park designs that favour a greater commitment to more intense PA, the papers reviewed indicate a positive association between access to parks and PA in children and a lower obesity rate [61,68,69,71], although previous review studies [87] did not find accessibility a significant factor in park use for PA. The offer of services increases the use of parks and encourages PA [62,93], with this being especially important for girls [94,95]. The diversity of sports fields (basketball, handball, soccer, baseball, etc.) can increase PA [63,96], although other studies such as those carried out by Spengler et al. [81] and Floyd et al. [97] do not support this idea, finding that organised activity in parks is not related to an increase in PA in younger children. These children are hardly interested in structured PA, but instead prioritise free and spontaneous play. Issues such as security [98,99], poor maintenance of facilities [100,101] and lack of adequate supervision [72] have been identified as the main obstacles to the use of parks and, consequently, with a reduction in PA [63]. Thus, good security and access to playgrounds improve active play [74]. On the other hand, some characteristics of public parks (such as play areas) have been associated with higher energy expenditure compared to other characteristics [67]. In children under 13 years of age, traditional playgrounds with swings and climbing equipment favour PA [102].

The designed or renovated playgrounds (innovative parks, Troyan Park, pocket parks, playscape parks, Krajicek parks and renovated parks for cold areas) that meet the preferences of children clearly increase PA $[4,53,56,62,64,69,77]$. However, other studies did not find significant differences from traditional parks in relation to increased PA [95].

Regarding the characteristics of the park that can influence the levels and intensity of PA, the studies identified that swings and sports facilities, especially basketball courts, pedestrian paths and different types of terrain surfaces $[63,67,74]$ (for example, grass, trees, hills, running water, and sand [103]) allow for a higher intensity of PA. The relationship between greenness and PA for children is similar to previous reviews, in which it is suggested that the green environment influences an increase in total PA [87]. Possibly the cause is the reduction of negative emotions and increased energy. Parks without benches [71,76] that include trails and cycling routes also increase the intensity of PA [75]. The relationship between trails/roads and park-based PA, also analysed by Zhang et al. [87] with consistent data, suggested that people are more likely to participate in walking, running and cycling in parks when trails/roads exist. Redevelopment of playgrounds is an effective strategy for increasing playground use and levels of moderate and vigorous 
PA in both boys [72] and girls [74]. However, according to the data of Reed et al. [79], the vast majority of observed PA is usually vigorous.

Finally, regarding motor skills development (MS), few studies have examined the role of playgrounds in the development of motor skills in children. Specifically, the present study has only identified two published works that detail the importance of playgrounds for this development $[61,67]$. It is necessary for parks to integrate a mix of structured and free play. At the same time, they must have equipment that allows directed and instructed play [67]. This is important because free activities, by themselves, do not promote the development of motor skills [104]. For this reason, contemporary playgrounds promote the development of locomotor skills such as walking and running, while adventure parks promote the development of skills such as climbing and maintaining balance [105]. The few papers found make these data not consistent, and more research is needed in the relationship of the characteristics of parks in relation to the development of motor skills.

When trying to establish concrete data on the perspectives and design of parks that promote children's health, the main limitations encountered were related to the diverse nature of physical environments and socioeconomic contexts. Additionally, the target groups vary considerably in terms of age, race, and health behaviours. Research that takes gender into account is also lacking.

More studies are needed to examine specific age ranges in depth. Studies should take into account the preferences of both boys and girls and, more specifically, should measure levels of physical fitness and motor skills. These are good indicators because they are worked on during visits to the park and go beyond the simple measurement of users' levels of physical activity.

\subsection{Limitations}

The limitations of the study are mainly centered on the lack of studies found, which also present very diverse data in terms of physical environments, target groups (sex, age and ethnicity) and health behaviours. These studies also present diverse research designs, making it difficult to obtain consistent data. There is a shortage of interventions that provide objective data on the effectiveness of park design in improving and increasing PA in school ages, so it has not been possible to carry out a meta-analysis.

\section{Conclusions}

Urban parks are a valuable resource for the promotion of PA in different socioeconomic contexts and especially in the most disadvantaged populations. The construction or redevelopment of parks should consider the needs of the population and the socioeconomic context. Involving community members in playground renovations can have a positive effect on park use and PA engagement in children.

Park selection differs depending on the age of users. Family members and caregivers of children aged 3-6 years prefer outdoor playgrounds with green areas and a variety of play areas. They prefer parks that are close to their homes that are safe. On the other hand, 8-12 year olds prefer larger parks with a variety of sports, comfort facilities and walking and cycling paths. It does not concern them if the park is far from their residence. Park safety is a highly valued aspect for parents of children in both age ranges.

Parks designed or remodelled to suit the preferences of children and their careers increase PA at different ages. This is, therefore, an effective strategy for maximising park use and PA engagement in children.

It is clear that aspects such as playground availability and proximity are associated with higher PA levels and, therefore, lower levels of childhood obesity. However, the gender of users was not a significant predictor of the PA levels observed in the parks included in the present study. 


\section{Future Perspectives}

Future studies should go deeper into the level of physical fitness and motor skills that are worked on during visits to the parks instead of measuring only the level of physical activity of users.

This systematic review is the prelude to a future project which will seek to analyse the reality of playgrounds in the city of Granada, as well as to plan interventions to optimise and promote the use and practice of PA in school-age children.

Author Contributions: Conceptualization, R.P.-R., Á.C.-J., M.E.P.-G. and D.C.-M.; methodology, M.E.P.-G. and R.P.-R.; formal analysis, R.P.-R. and M.E.P.-G.; investigation, R.P.-R. and M.E.P.-G.; data curation, R.P.-R. and M.E.P.-G.; writing-original draft preparation, R.P.-R., Á.C.-J., M.E.P.-G. and D.C.-M.; writing—review and editing, R.P.-R., M.E.P.-G. and D.C.-M.; visualization, R.P.-R., Á.C.-J., M.E.P.-G. and D.C.-M.; supervision, D.C.-M., R.P.-R. and M.E.P.-G. All authors have read and agreed to the published version of the manuscript.

Funding: This research received no external funding.

Institutional Review Board Statement: Not applicable.

Informed Consent Statement: Not applicable.

Data Availability Statement: Data is contained within the article or supplementary material.

Conflicts of Interest: The authors declare no conflict of interest.

\section{References}

1. World Health Organization: WHO. Actividad Física. Available online: https://www.who.int/es/news-room/fact-sheets/detail/ physical-activity (accessed on 23 February 2018).

2. Mikalsen, H.K.; Lagestad, P.A. Adolescents' meaning-making experiences in physical education-In the transition from primary to secondary school. Sport Educ. Soc. 2019, 24, 1-13. [CrossRef]

3. Priesmeyer, J.; Fedewa, A.L.; Toland, M. Long-Term Trends of Participation in Physical Activity during Adolescence with Educational Ambition and Attainment. J. Sch. Health 2019, 89, 20-30. [CrossRef]

4. Boonzajer, S.; Chinapaw, M.; Koolhaas, C.M.; van Mechelen, W.; Verhagen, E. More children more active: Tailored playgrounds positively affect physical activity levels amongst youth. J. Sport Sci. Med. 2016, 19, 250-254. [CrossRef]

5. Deng, J.R.; Tan, W.Q.; Yang, S.Y.; Ao, L.P.; Liang, J.P.; Li, L.X.; Gao, Y.H.; Yang, Y.; Liu, L. High birth weight and its interaction with physical activity influence the risk of obesity in early school-aged children. WJP 2020, 16, 385-392. [CrossRef]

6. Omorou, A.Y.; Manneville, F.; Langlois, J.; Legrand, K.; Böhme, P.; Muller, L.; Guillemin, F.; Briançon, S.; Lecomtec, E.; PRALIMAPINÈS Trial Group. Physical activity rather than sedentary behaviour is socially determined in French adolescents with overweight and obesity. Prev. Med. 2020, 134, 106043. [CrossRef]

7. Cigarroa, I.; Sarqui, C.; Zapata-Lamana, R. Efectos del sedentarismo y obesidad en el desarrollo psicomotor en niños y niñas: Una revisión de la actualidad latinoamericana. Rev. Univ. Salud 2016, 18, 156-169. [CrossRef]

8. Matarma, T.; Lagström, H.; Hurme, S.; Tammelin, T.H.; Kulmala, J.; Barnett, L.M.; Koski, P. Motor skills in association with physical activity, sedentary time, body fat, and day care attendance in 5-6-year-old children-The STEPS Study. Scand. J. Med. Sci. Sports 2018, 28, 2668-2676. [CrossRef]

9. Greenspan, S.B.; Fefer, S.A.; Whitcomb, S.A.; Kemp, J.M. Incorporating physical activity-based interventions in school psychology research and practice: A systematic review. Psychol. Sch. 2019, 56, 907-927. [CrossRef]

10. Vásquez-Bonilla, A.A.; Zelaya-Paz, C.; García-Aguilar, J. Análisis de sobrepeso y obesidad, niveles de actividad física y autoestima en escolares de San Pedro Sula, Honduras. Mhsalud 2019, 16, 1-14. [CrossRef]

11. Tarraga, P.J.J.; Garcia, E.; Rodriguez, P.L.; Perez, J.J.; Rosa, A.; Tarraga, M.L. Actividad física, condición física y estatus nutricional en escolares de 8 a 12 años. Physical activity, physical fitness and nutritional status in schoolchildren from 8 to 12 years. Nutr. Hosp. 2017, 34, 1265-1516. [CrossRef]

12. Hakala, J.O.; Rovio, S.P.; Pahkala, K.; Nevalainen, J.; Juonala, M.; Hutri-Kähönen, N.; Heinonen, O.L.; Hirvensalo, M.; Telama, R.; Viikari, J.S.; et al. Physical Activity from Childhood to Adulthood and Cognitive Performance in Midlife. Med. Sci. Sports Exerc. 2019, 51, 882-890. [CrossRef]

13. Rhodes, R.E.; Blanchard, C.M.; Quinlan, A.; Naylor, P.-J.; Warburton, D.E.R. Family Physical Activity Planning and Child Physical Activity Outcomes: A Randomized Trial. Am. J. Prev. Med. 2019, 57, 135-144. [CrossRef]

14. Poeta, M.; Lamberti, R.; Di Salvio, D.; Massa, G.; Torsiello, N.; Pierri, L.; Delli Bovi, A.P.; Di Michele, L.; Guercio Nuzio, S.; Vajro, P. Waist Circumference and Healthy Lifestyle Preferences/Knowledge Monitoring in a Preschool Obesity Prevention Program. Nutrients 2019, 11, 2139. [CrossRef] 
15. Haines, J.; Haycraft, E.; Lytle, L.; Nicklaus, S.; Kok, F.J.; Merdji, M.; Fisberg, M.; Moreno, L.A.; Goulet, O.; Hughes, S.O. Nurturing Children's Healthy Eating: Position statement. Appetite 2019, 137, 124-133. [CrossRef]

16. Castro-Sánchez, M.; Zurita-Ortega, F.; García-Marmol, E.; Chacón-Cuberos, R. Motivational Climate in Sport Is Associated with Life Stress Levels, Academic Performance and Physical Activity Engagement of Adolescents. Int. J. Environ. Res. Public Health 2019, 16, 1198. [CrossRef]

17. Korczak, D.J.; Madigan, S.; Colasanto, M. Children's Physical Activity and Depression: A Meta-analysis. Pediatrics 2017, 139, e20162266. [CrossRef]

18. Pate, R.R.; Hillman, C.H.; Janz, K.F.; Katzmarzyk, P.T.; Powell, K.E.; Torres, A.; Whitt-Glover, M.C. Physical Activity and Health in Children Younger than 6 Years. Med. Sci. Sports Exerc. 2019, 51, 1282-1291. [CrossRef]

19. Brown, D.; Leledaki, A. Eastern Movement Forms as Body-Self Transforming Cultural Practices in the West: Towards a Sociological Perspective. Cult. Sociol. 2010, 4, 123-154. [CrossRef]

20. Moore, E.W.; Fry, M.D. Physical Education Students' Ownership, Empowerment, and Satisfaction with PE and Physical Activity. Res. Q. Exerc. Sport 2017, 88, 468-478. [CrossRef] [PubMed]

21. Quennerstedt, M. Healthying physical education -on the possibility of learning health. Phys. Educ. Sport Pedagog. 2019, 24, 1-15. [CrossRef]

22. Carson, V.; Lee, E.Y.; Hewitt, L.; Jennings, C.; Hunter, S.; Kuzik, N.; Stearns, J.A.; Unrau, S.P.; Poitras, V.J.; Gray, C.; et al. Systematic review of the relationships between physical activity and health indicators in the early years (0-4 years). BMC Public Health 2017, 17, 33-57. [CrossRef]

23. Stanley, R.M.; Jones, R.A.; Cliff, D.P.; Trost, S.G.; Berthelsen, D.; Salmon, J.; Batterham, M.; Eckermann, S.; Reilly, J.J.; Brown, $\mathrm{N}$; i et al. Increasing physical activity among young children from disadvantaged communities: Study protocol of a group randomised controlled effectiveness trial. BMC Public Health 2016, 16, 1095. [CrossRef] [PubMed]

24. Timmons, B.W.; LeBlanc, A.G.; Carson, V.; Connor, S.; Dillman, C.; Janssen, I.; Kho, M.; Spence, J.C.; Stearns, J.; Tremblay, M.S. Systematic review of physical activity and health in the early years (aged 0-4 years). Appl. Physiol. Nutr. Metab. 2012, 37, 773-792. [CrossRef] [PubMed]

25. Bidzan-Bluma, I.; Lipowska, M. Physical Activity and Cognitive Functioning of Children: A Systematic Review. Int. J. Environ. Res. Public Health 2018, 15, 800. [CrossRef]

26. McPherson, A.; Mackay, L.; Kunkel, J.; Duncan, S. Physical activity, cognition and academic performance: An analysis of mediating and confounding relationships in primary school children. BMC Public Health 2018, 18, 936. [CrossRef]

27. Watson, A.; Timperio, A.; Brown, H.; Best, K.; Hesketh, K.D. Effect of classroom-based physical activity interventions on academic and physical activity outcomes: A systematic review and meta-analysis. Int. J. Behav. Nutr. Phys. Act. 2017, 14, 114. [CrossRef] [PubMed]

28. Márquez, J.J. Physical inactivity, exercise and pandemic COVID-19. Viref Rev. Educ. Física 2020, 9. Available online: https: / / revistas.udea.edu.co/index.php/viref/article/view/342196/20802578 (accessed on 30 March 2021).

29. Villaquirán, A.F.; Ramos, O.A.; Jimena, S.; Meza, M.M. Physical activity and exercise in COVID-19. Rev. CES Med. 2020, 51-58. Available online: https:/ / revistas.ces.edu.co/index.php/medicina/article/view/5530 (accessed on 30 March 2021).

30. Romar, J.-E.; Enqvist, I.; Kulmala, J.; Kallio, J.; Tammelin, T. Physical activity and sedentary behaviour during outdoor learning and traditional indoor school days among Finnish primary school students. J. Adventure Educ. Outdoor Learn. 2018, 19, 28-42. [CrossRef]

31. Roslund, M.I.; Puhakka, R.; Grönroos, M.; Nurminen, N.; Oikarinen, S.; Gazali, A.M.; Cinek, O.; Kramná, L.; Siter, N.; Vari, H.K.; et al. Biodiversity intervention enhances immune regulation and health-associated commensal microbiota among daycare children. Sci. Adv. 2020, 6, eaba2578. [CrossRef]

32. Ahmetoglu, E. The contributions of familial and environmental factors to children's connection with nature and outdoor activities. Early Child Dev. Care 2017, 189, 233-243. [CrossRef]

33. Brown, D.H.K. Seeking spirituality through physicality in schools: Learning from "Eastern movement forms". Int. J. Child. Spirit. 2013, 18, 30-45. [CrossRef]

34. Brown, D.H.K.; Jennings, G.; Sparkes, A.C. Taijiquan the "Taiji World" Way: Towards a Cosmopolitan Vision of Ecology. Societies 2014, 4, 380-398. [CrossRef]

35. Bandura, A. Human agency in social cognitive theory. Am. Psychol. 1989, 44, 1175-1184. [CrossRef] [PubMed]

36. Bandura, A. Health promotion from the perspective of social cognitive theory. Psychol. Health 1998, 13, 623-649. [CrossRef]

37. Bandura, A. Health promotion by social cognitive means. Health Educ. Behav. 2004, 31, 143-164. [CrossRef] [PubMed]

38. Bronfenbrenner, U. The ecology of human development: History and perspectives. Psychol. Wychowawcza 1976, 19, 537-549.

39. Bronfenbrenner, U. Lewinian space and ecological substance. JSI 1977, 33, 199-212. [CrossRef]

40. Bronfenbrenner, U. Toward an experimental ecology of human development. Am. Psychol. 1977, 32, 513-531. [CrossRef]

41. Sallis, J.F.; Owen, N. Ecological Models of Health Behaviour. In Health Behaviour and Health Education: Theory, Research and Practice, 3rd ed.; Glanz, K., Rimer, B., Lewis, F., Eds.; Jossey-Bass: San Francisco, CA, USA, 2002; pp. 462-484.

42. Cradock, A.L.C.; Ducnan, D.T. The role of the built environment in supporting healthbehavior change. In The Handbook of Health Behavior Change, 4th ed.; Riekert, K.A., Ockene, J.K., Pbert, L., Eds.; Springer Publishing Company: New York, NY, USA, 2013; pp. 437-462. [CrossRef] 
43. Hammink, C.; Moor, N.; Mohammadi, M. A systematic literature review of persuasive architectural interventions for stimulating health behaviour. Facilities 2019, 37, 743-761. [CrossRef]

44. Luszczynska, A.; Schwarzer, R. Social cognitive theory. In Buckingham, England: Predicting Health Behaviour, 2nd ed.; Conner, M., Norman, P., Eds.; Open University Press: Buckingham, UK, 2005; pp. 127-169.

45. Chow, H.W.; Wu, D.R. Outdoor Fitness Equipment Usage Behaviors in Natural Settings. Int. J. Environ. Res. Public Health 2019, 16, 391. [CrossRef] [PubMed]

46. Børve, H.E.; Børve, E. Rooms with gender: Physical environment and play culture in kindergarten. Early Child. Dev. Care 2016, 187, 1069-1081. [CrossRef]

47. Kaymaz, I.; Oguz, D.; Cengiz-Hergul, O.C. Factors influencing children's use of urban green spaces. Indoor Built Environ. 2017, 28, 520-532. [CrossRef]

48. Lachowycz, K.; Jones, A.P.; Page, A.S.; Wheeler, B.W.; Cooper, A.R. What can global positioning systems tell us about the contribution of different types of urban greenspace to children's physical activity? Health Place 2012, 18, 586-594. [CrossRef] [PubMed]

49. Flowers, E.P.; Timperio, A.; Hesketh, K.D.; Veitch, J. Comparing the features of parks that children usually visit with those that are closest to home: A brief report. Urban For. Urban Green. 2020, 48, 126560. [CrossRef]

50. Loukaitou-Sideris, A.; Sideris, A. What Brings Children to the Park? Analysis and Measurement of the Variables Affecting Children's Use of Parks. JAPA 2009, 76, 89-107. [CrossRef]

51. Ou, J.Y.; Levy, J.I.; Peters, J.L.; Bongiovanni, R.; Garcia-Soto, J.; Medina, R.; Scammell, M.K. A Walk in the Park: The Influence of Urban Parks and Community Violence on Physical Activity in Chelsea, MA. Int. J. Environ. Res. Public Health 2016, 13, 97. [CrossRef]

52. Qin, Q.; Nakamura, K.W.; Yamamoto, K.; Shimomura, A. A Study on Changes to the Form of Children's Playgrounds in Japan by Analyzing the JILA Selected Works of Landscape Architecture. Sustainability 2019, 11, 2127. [CrossRef]

53. Talarowski, M.; Cohen, D.A.; Williamson, S.; Han, B. Innovative playgrounds: Use, physical activity, and implications for health. Public Health 2019, 174, 102-109. [CrossRef]

54. Hyndman, B.P.; Telford, A. Should Educators be 'Wrapping School Playgrounds in Cotton Wool' to Encourage Physical Activity? Exploring Primary and Secondary Students' Voices from the School Playground. AJTE 2015, 40, 60-84. [CrossRef]

55. Bancroft, C.; Joshi, S.; Rundle, A.; Hutson, M.; Chong, C.; Weiss, C.C.; Jeanine Genkinger, J.; Neckerman, K.; Lovasi, G. Association of proximity and density of parks and objectively measured physical activity in the United States: A systematic review. Soc. Sci. Med. 2015, 138, 22-30. [CrossRef]

56. Roemmich, J.N.; Johnson, M.S. Seasonal Alterations in Park Visitation, Amenity Use, and Physical Activity-Grand Forks, North Dakota, 2012-2013. Prev. Chronic Dis. 2014, 11, 140175. [CrossRef]

57. Veitch, J.; Flowers, E.; Ball, K.; Deforche, B.; Timperio, A. Exploring Children's Views on Important Park Features: A Qualitative Study Using Walk-Along Interviews. Int. J. Environ. Res. Public Health 2020, 17, 4625. [CrossRef]

58. Hutton, B.; Salanti, G.; Caldwell, D.; Chaimani, A.; Schmid, C.; Cameron, C.; Ioannidis, J.; Straus, S.; Thorlund, K.; Jansen, J.; et al. The PRISMA extension statement for reporting of systematic reviews incorporating net work meta-analyses of health care interventions: Checklist and explanations. Ann. Intern. Med. 2015, 162, 777-784. [CrossRef]

59. Urrútia, G.; Bonfill, X. Declaración PRISMA: Una propuesta para mejorar la publicación de revisiones sistemáticas y metaanálisis. Med. Clin. 2010, 135, 507-511. [CrossRef]

60. Flowers, E.P.; Timperio, A.; Hesketh, K.D.; Veitch, J. Examining the Features of Parks That Children Visit During Three Stages of Childhood. Int. J. Environ. Res. Public Health 2019, 16, 1658. [CrossRef]

61. Gil-Madrona, P.; Martinez-Lopez, M.; Prieto-Ayuso, A.; Saraiva, L.; Vecina-Cifuentes, J.; Vicente-Ballesteros, T.; Moratilla-López, R.; Lopez-Sanchez, G.F. Contribution of Public Playgrounds to Motor, Social, and Creative Development and Obesity Reduction in Children. Sustainability 2019, 11, 3787. [CrossRef]

62. Lal, A.; Moodie, M.; Abbott, G.; Carver, A.; Salmon, J.; Giles-Corti, B.; Timperio, A.; Veitch, J. The impact of a park refurbishment in a low socioeconomic area on physical activity: A cost-effectiveness study. Int. J. Behav. Nutr. Phys. 2019, 16. [CrossRef]

63. Marquet, O.; Hipp, J.A.; Alberico, C.; Huang, J.-H.; Fry, D.; Mazak, E.; Lovasi, G.S.; Floyd, M.F. Park use preferences and physical activity among ethnic minority children in low-income neighborhoods in New York City. Urban For. Urban. Green. 2019, 38, 346-353. [CrossRef]

64. Parra, D.C.; Van Zandt, A.; Wang, P.; Goodman, M.; Abhishek, J.; Haire-Joshu, D.; Brownson, R.C. Evaluating Park Use and Satisfaction: The Case of Trojan Park in St. Louis Missouri. Int. J. Environ. Res. Public Health 2019, 16, 2798. [CrossRef]

65. Qiao, S. Organizing play spaces for children in China's megalopolises: Preferences and requirements of parents. Early Child. Dev. Care 2019, 1-13. [CrossRef]

66. Washington, T.L.; Cushing, D.F.; Mackenzie, J.; Buys, L.; Trost, S. Fostering Social Sustainability through Intergenerational Engagement in Australian Neighborhood Parks. Sustainability 2019, 11, 4435. [CrossRef]

67. Adams, J.; Veitch, J.; Barnett, L. Physical Activity and Fundamental Motor Skill Performance of 5-10 Year Old Children in Three Different Playgrounds. Int. J. Environ. Res. Public Health 2018, 15, 1896. [CrossRef]

68. Rossi, C.E.; Correa, E.N.; das Neves, J.; García, C.; Benedet, J.; Rech, C.R.; Guedes, F.A. Body mass index and association with use of and distance from places for physical activity and active leisure among schoolchildren in Brazil. Cross-sectional study. Sao Paulo Med. J. 2018, 136, 228-236. [CrossRef] 
69. Veitch, J.; Salmon, J.; Crawford, D.; Abbott, G.; Giles-Corti, B.; Carver, A.; Timperio, A. The REVAMP natural experiment study: The impact of a play-scape installation on park visitation and park-based physical activity. Int. J. Behav. Nutr. Phys. 2018, 15, 10. [CrossRef]

70. Bezold, C.P.; Stark, J.H.; Rundle, A.; Konty, K.; Day, S.E.; Quinn, J.; Neckerman, K.; Roux, A.V.D. Relationship between Recreational Resources in the School Neighborhood and Changes in Fitness in New York City Public School Students. J. Urban Health 2017, 94, 20-29. [CrossRef]

71. McCarthy, S.M.; Hughey, M.; Kaczynki, A.T. Examining Sociodemographic Differences in Playground Availability and Quality and Associations with Childhood Obesity. Child. Obes. 2017, 13, 324-331. [CrossRef]

72. Slater, S.; Pugach, O.; Lin, W.; Bontu, A. If You Build It Will They Come? Does Involving Community Groups in Playground Renovations Affect Park Utilization and Physical Activity? Environ. Behav. 2016, 48, 246-265. [CrossRef]

73. Arroyo-Johnson, C.; Woodward, K.; Milam, L.; Ackermann, N.; Komaie, G.; Goodman, M.S.; Hipp, J.A. Still Separate, Still Unequal: Social Determinants of Playground Safety and Proximity Disparities in St. Louis. J. Urban Health Bull. N. Y. Acad. Med. 2016, 93, 627-638. [CrossRef]

74. Baek, S.; Epstein, L.H.; Yin, L.; Roemmich, J.N. Park design and children's active play: A microscale spatial analysis of intensity of play in Olmsted's Delaware Park. Environ. Plan. B Plan. Des. 2015, 42, 1079-1097. [CrossRef]

75. Schipperijn, J.; Hansen, C.K.; Rask, S. Use and activity levels on newly built bicycle playgrounds. Urban For. Urban Green. 2015, 14, 163-169. [CrossRef]

76. Roemmich, J.N.; Beeler, J.E.; Johnson, M.S. A microenvironment approach to reducing sedentary time and increasing physical activity of children and adults at a playground. Prev. Med. 2014, 62, 108-112. [CrossRef]

77. Cohen, D.A.; Marsh, T.; Williamson, S.; Han, B.; Derose, K.P.; Golinelli, D.; McKenzie, T.L. The Potential for Pocket Parks to Increase Physical Activity. Am. J. Health Promot. 2014, 28, 19-26. [CrossRef]

78. Nasar, J.L.; Holloman, C.H. Playground Characteristics to Encourage Children to Visit and Play. J. Phys. Act. Health 2013, 10, 1201-1208. [CrossRef]

79. Reed, J.A.; Hooker, S.P. Where are youth physically active? A descriptive examination of 45 parks in a southeastern community. Child. Obes. 2012, 8, 124-131. [CrossRef]

80. Colabianchi, N.; Maslow, A.L.; Swayampakala, K. Features and amenities of school playgrounds: A direct observation study of utilization and physical activity levels outside of school time. Int. J. Behav. Nutr. Phys. Act. 2011, 8, 1-11. [CrossRef]

81. Spengler, J.; Floyd, M.F.; Maddock, J.E.; Gobster, P.H.; Suau, L.J.; Gregory, J. Norman. Correlates of Park-Based Physical Activity Among Children in Diverse Communities: Results from an Observational Study in Two Cities. AJHP 2011, 25, 1-9. [CrossRef]

82. Quigg, R.; Gray, A.; Reeder, A.I.; Holt, A.; Waters, D.L. Using accelerometers and GPS units to identify the proportion of daily physical activity located in parks with playgrounds in New Zealand children. Prev. Med. 2010, 50, 235-240. [CrossRef]

83. Jansson, M.; Persson, B. Playground planning and management: An evaluation of standard-influenced provision through user needs. Urban For. Urban Green. 2010, 9, 33-42. [CrossRef]

84. González-Valero, G.; Zurita-Ortega, F.; Ubago-Jiménez, J.L.; Puertas-Molero, P. Use of meditation and cognitive behavioral therapies for the treatment of stress, depression and anxiety in students. A systematic review and meta-analysis. Int. J. Environ. Res. Public Health 2019, 16, 4394. [CrossRef]

85. Hallal, P.C.; Andersen, L.B.; Bull, F.C.; Guthold, R.; Haskell, W.; Ekelund, U.; Lancet Physical Activity Series Working Group. Global physical activity levels: Surveillance progress, pitfalls, and prospects. Lancet 2012, 380, 247-257. [CrossRef]

86. Peña-de León, A.; Amezcua-Núñez, J.B.; Hernández-Bonilla, A. La promoción de estilos de vida saludable aprovechando los espacios públicos. Horiz. Sanit. 2017, 16, 201-210. [CrossRef]

87. Zhang, R.; Wulff, H.; Duan, Y.; Wagner, P. Associations between the Physical Environment and Park-Based Physical Activity: A Systematic Review. J. Sport Health Sci. 2018, 8, 412-421. [CrossRef]

88. Schultz, C.L.; Wilhelm, S.A.; Sayers, S.P.; Thombs, L.A.; Thomas, I.M. A longitudinal examination of improved access on park use and physical activity in a low-income and majority African American neighborhood park. Prev. Med. 2017, 95, 95-100. [CrossRef]

89. Schipperijn, J.; Bentsen, P.; Troelsen, J.; Toftager, M.; Stigsdotter, U.K. Associations between physical activity and characteristics of urban green space. Urban For. Urban Green. 2013, 12, 109-116. [CrossRef]

90. Audrey, S.; Batista-Ferrer, H. Healthy urban environments for children and young people: A systematic review of intervention studies. Health Place 2015, 36, 97-117. [CrossRef]

91. Sefcik, J.S.; Kondo, M.C.; Klusaritz, H.; Sarantschin, E.; Solomon, S.; Roepke, A.; South, E.C.; Jacoby, S.F. Perceptions of Nature and Access to Green Space in Four Urban Neighborhoods. Int. J. Environ. Res. Public Health 2019, 16, 2313. [CrossRef]

92. Van Hecke, L.; Ghekiere, A.; Veitch, J.; Van Dyck, D.; Van Cauwenberg, J.; Clarys, P.; Deforche, B. Public open space characteristics influencing adolescents' use and physical activity: A systematic literature review of qualitative and quantitative studies. Health Place 2018, 51, 158-173. [CrossRef]

93. Baylina, M.; Ortiz, A.; Prats, M. Children and playgrounds in Mediterranean cities. Child. Geogr. 2006, 4, 173-183. [CrossRef]

94. Bohn-Goldbaum, E.E.; Phongsavan, P.; Merom, D.; Rogers, K.; Kamalesh, V.; Bauman, A.E. Does playground improvement increase physical activity among children? A quasi-experimental study of a natural experiment. J. Environ. Public Health 2013, 109841. [CrossRef]

95. Edwards, N.; Hooper, P.; Knuiman, M.; Foster, S.; Giles-Corti, B. Associations between park features and adolescent park use for physical activity. Int. J. Behav. Nutr. Phys. Act. 2015, 12, 1-10. [CrossRef] 
96. Cohen, D.A.; Han, B.; Derose, K.P.; Williamson, S.; Marsh, T.; Raaen, L.; McKenzie, T.L. The paradox of parks in low-income areas: Park use and perceived threats. Environ. Behav. 2016, 48, 230-245. [CrossRef]

97. Floyd, M.F.; Bocarro, J.N.; Smith, W.R.; Baran, P.K.; Moore, R.C.; Cosco, N.G.; Edwards, M.B.; Suau, L.J.; Fang, K. Park-Based Physical Activity Among Children and Adolescents. Am. J. Prev. Med. 2011, 41, 258-265. [CrossRef]

98. Cronan, M.; Shinew, K.; Schneider, I.; Wilhelm, S.; Chavez, D. Physical activity patterns and preferences among Latinos in different types of public parks. JPAH 2008, 5, 894-908. [CrossRef] [PubMed]

99. Wilbur, J.; Chandler, P.; Dancy, B.; Choi, J.; Plonczynski, D. Environmental, policy, and cultural factors related to physical activity in urban, African-American women. Women Health 2002, 36, 17-28. [CrossRef]

100. Penilla, C.; Tschann, J.M.; Sanchez-Vaznaugh, E.V.; Flores, E.; Ozer, E.J. Obstacles to preventing obesity in children aged 2 to 5 years: Latino mothers' and fathers' experiences and perceptions of their urban environments. Int. J. Behav. Nutr. Phys. Act. 2017, 14, 1-12. [CrossRef]

101. Torres, M.E.; Meetze, E.G.; Smithwick-Leone, J. Latina voices in childhood obesity a pilot study using photovoice in South Carolina. Am. J. Prev. Med. 2013, 44, 225-231. [CrossRef] [PubMed]

102. Lindberg, M.; Schipperijn, J. Active use of urban park facilities: Expectations versus reality. Urban For. Urban. Green. 2015, 14, 909-918. [CrossRef]

103. Fjørtoft, I. Landscape as playscape: The effects of natural environments on children's play and motor development. Child. Youth Environ. 2004, 14, 21-44. [CrossRef]

104. Tortella, P.; Fumagalli, G.; Loras, H.; Haga, M.; Sigmundsson, H. Exploring the effects and specificity of playground activities on motor skills in 5 years old children. Sci. Sports 2014, 29, 50. [CrossRef]

105. Suttervy, J.; Thornton, C. It doesn't just happen! Essential contributions from playgrounds. Young Child. 2005, 60, 26-33. 